\title{
Multiple approaches to identify bacteria in archaeological waterlogged wood
}

\author{
Franco Palla*, Francesco Paolo Mancuso, Noemi Billeci \\ Dipartimento di Biologia Ambientale e Biodiversità, Laboratorio di Biologia Molecolare, via Archirafi 28 - 90123 Palermo, Italy
}

\section{A R T I C L E I N F O}

\section{Article history:}

Received 25 October 2012

Accepted 5 November 2012

Available online 12 February 2013

\section{Keywords:}

Biodeterioration

SEM

Microbial DNA

Polymerase chain reaction

Internal transcribed spacer

\begin{abstract}
A B S T R A C T
This study was carried out in collaboration with Soprintendenza del Mare (SM) that started, since 2004, to plan and realize underwater archaeological parks, such as in the Sicilian islands of Pantelleria (Gadir), Levanzo (Cala Minnola), Ustica (Falconiera), Panarea (Basiluzzo) and Filicudi (Capo Graziano). In situ conservation, as well as virtual exhibitions of the same topics, can contribute to ensure the protection and best fruition of underwater cultural heritage. The focus of this study was the identification of bacterial colonies in waterlogged wood samples from the rostrum of a excellent workmanship, that is very likely one of the wrecks attributed to Sextus Pompey fleet (36 BC) and discovered in Acqualadroni, Messina, Sicily, Italy (2008). Samples were analyzed by light and Scanning Electron Microscopy (SEM), in vitro culture and molecular technique (DNA base techniques). The results, focused on bacterial consortia, allowed us to reveal the presence of Pseudomonas sp., Sphingomonas sp., Xanthomonas sp. besides Marinobacter sp. and Desulforudis audaxviator. A prompt and accurate characterization of bacterial colonization represents one of the preliminary step in preservation/restoration projects, especially for waterlogged wood since the metabolic activity of specific bacteria induce and accelerate the deterioration processes. Although it is reported in a case study, this multiple approach is useful for reveal and identify bacterial colonizing both organic and inorganic artifacts.
\end{abstract}

(c) 2013 Elsevier Masson SAS. All rights reserved.

\section{Introduction and research aims}

Sicily is one of the most important places in the Mediterranean to study underwater archaeology, mainly due to its central position and its historical role [1].

The state of conservation of submerged archaeological wood depends on the factors closely related to site peculiarity, such as temperature, salinity and oxygen concentration [2]. Bacterial degradation of findings can be manifested in different ways, in relationship with the metabolic activities. The consequence is the loss of some structural components of the wood, such as cellulose, lignin, hemi-cellulose and thus the loss of the original chemical, physical and mechanical properties. Knowledge on microbial deterioration assume great importance for both archaeologists and conservators, and as reported in literature, fungi and bacteria play a critical role in the conservation of almost all cultural assessment, including archaeological wood [3-5]. Recently, fungal colonization has been well described during the drainage of wetlands [6] and two main bacterial species: erosion bacteria (submerged archaeological wood) and tunnelling bacteria (soft rot environments) were pointed out $[7,8]$. Usually, waterlogged archaeological wood

\footnotetext{
* Corresponding author. Tel.: +3909123891224

E-mail address: franco.palla@unipa.it (F. Palla).
}

presents a fragile inner structure and it needs special attentions in order to reduce the impact of conservation strategies [9].

In this study, small wood fragments from Mediterranean Sea area (Acqualadroni, Messina, Sicily), were analyzed in order to identify the wood and to evaluate the state of conservation, mainly in relationship to bacterial colonization. Light and Scanning Electron Microscopy (SEM), in combination with in vitro culture and molecular analysis demonstrated the presence of bacterial species.

\section{Materials and methods}

Wood fragments were collected by sterile scalpel and loops from three sites of the rostrum, as shown in Fig. 1 (RA 1, RA 2, RA 3 ) and utilized for both direct extraction of microbial DNA and inoculation of Nutrient agar plates (NA-Difco). After incubation at $30^{\circ} \mathrm{C}$ for $18 \mathrm{~h}$, single bacterial colonies have been isolated from the $\mathrm{N}$-agar plates [10].

Total bacterial DNA was extracted from wood fragments by Stool Mini Kit (Qiagen), partially modified [11]. DNA from single bacterial colony grew on NA plates, was obtained by cellular lyses at $94^{\circ} \mathrm{C}$ for $2 \mathrm{~min}$. Genomic DNA ( $5 \mu \mathrm{l}$ aliquots of lyses solution) were utilized as template in PCR reactions.

Specific ribosomal DNA sequences, 165 gene or ITS (Internal Transcribed Spacer) were respectively amplified by specific or universal primers. 


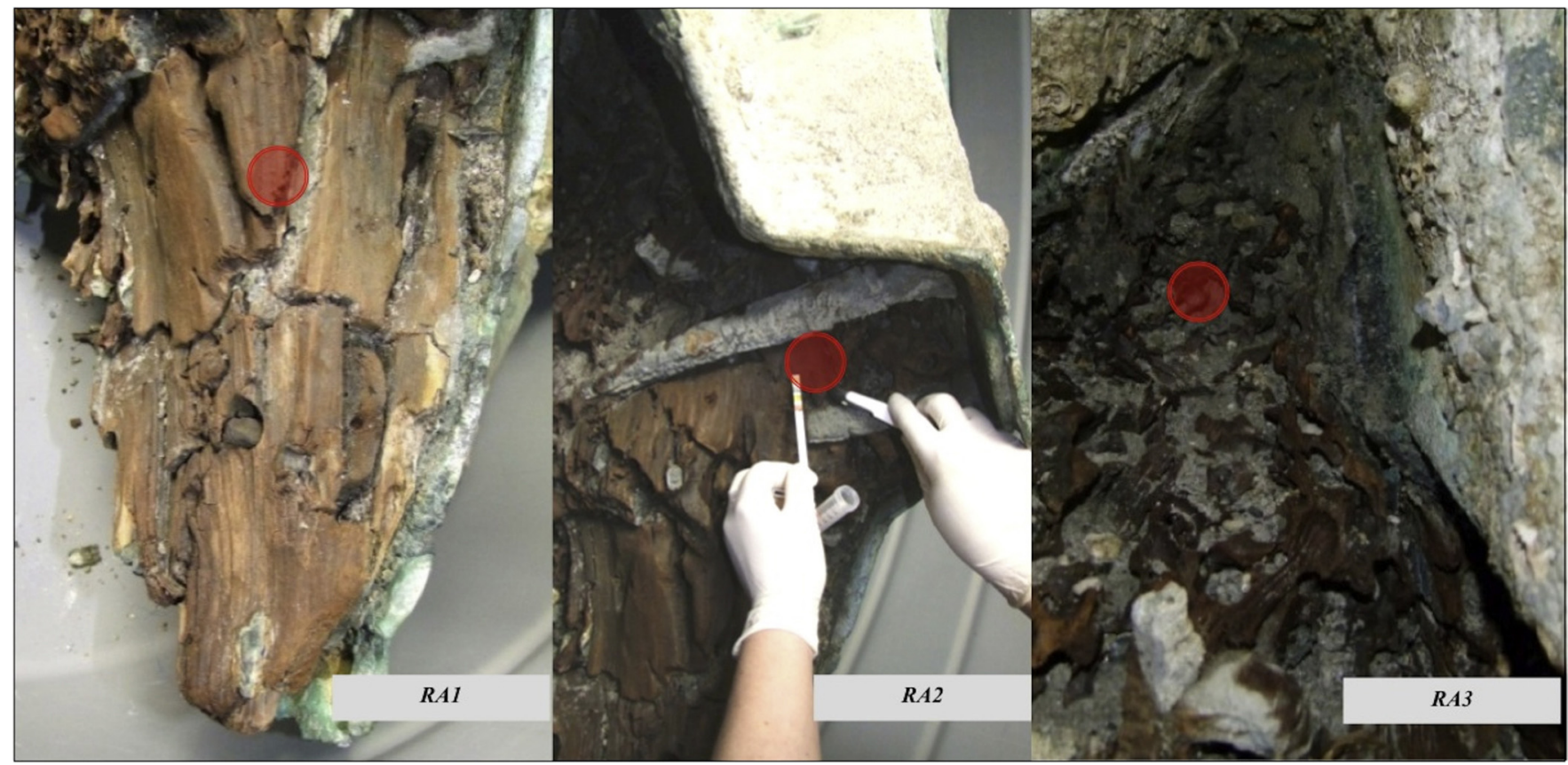

Fig. 1. Wood fragments sampling from different areas (pointed in red) of the wood rostrum structure.

Primers specific for 16 S gene were utilized to identify Cytophaga, Cellvibrio and Pseudomonas bacterial species $[12,13]$.

Universal primers, specific for 16S-23S rDNA - ITS region, were utilized as described in $[10,14]$.

The PCR reaction mixture, up to $50 \mu \mathrm{l}$, consisted of: genomic bacterial DNA ( $5 \mu$ l of lyses solution of single colony or 40 ng extracted from wooden fragments), $1 \times$ Reaction Buffer, $10 \mu \mathrm{M}$ forward primer, $10 \mu \mathrm{M}$ reverse primer, $2 \mu \mathrm{M}$ dNTP (deossinucleotidetriphosphate) mix, $2 \mathrm{mM} \mathrm{MgCl}_{2}, 5 \mathrm{U} / \mu \mathrm{l}$ Taq DNA polymerase (Invitrogen).

PCR reactions were performed in a Eppendorf Mastercycler gradient by the following amplification profiles: 1 cycle of initial denaturation at $95^{\circ} \mathrm{C}$ for $5 \mathrm{~min}$; 30 cycles as follows: denaturation at $94{ }^{\circ} \mathrm{C}$ for $1 \mathrm{~min}$, annealing at $50-58^{\circ} \mathrm{C}$ for $1 \mathrm{~min}$, extension at

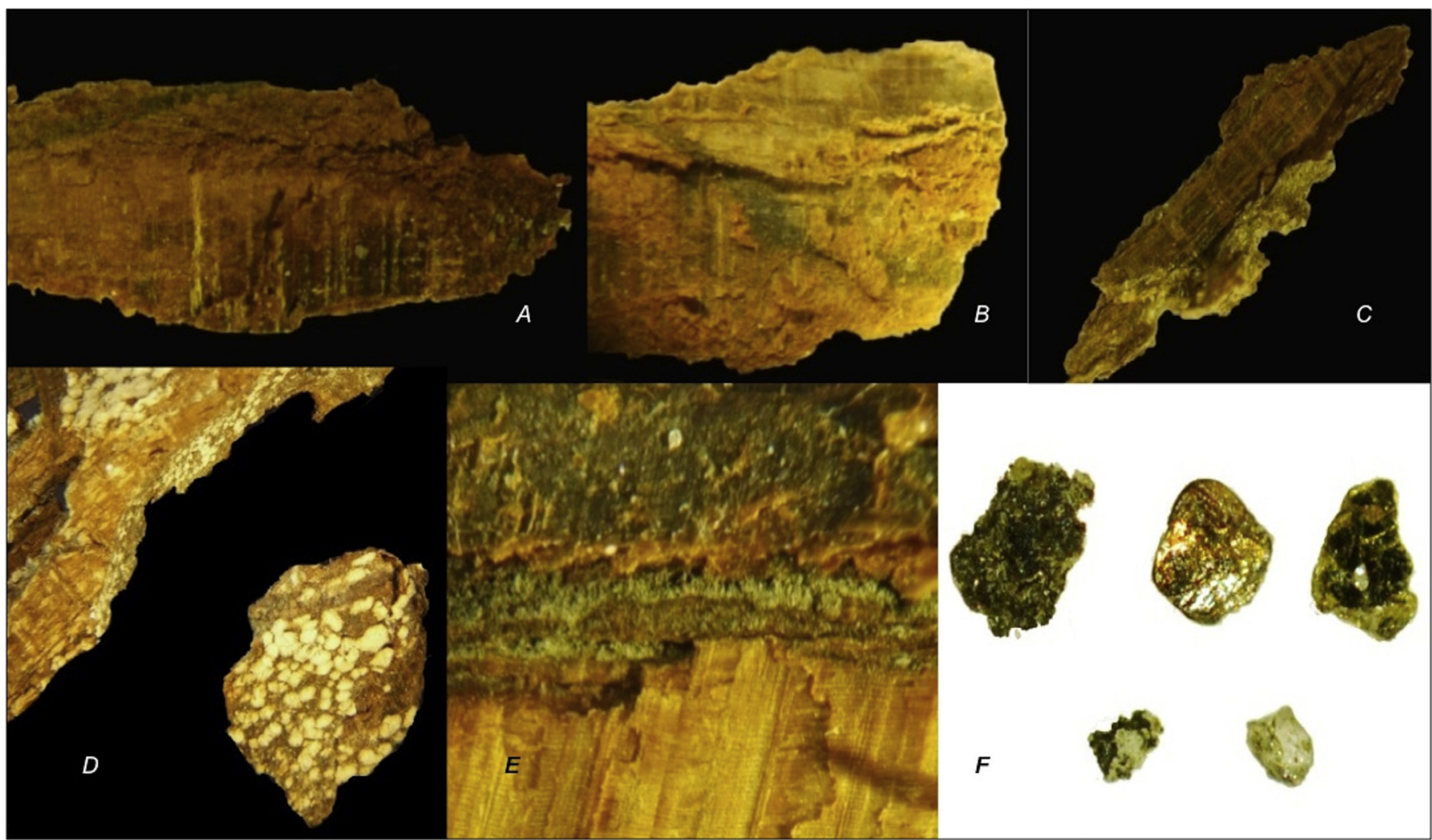

Fig. 2. Stereoscope images (radial and cross sections) of wood fragments. Deposits and chromatic alterations (green-dark spots). 


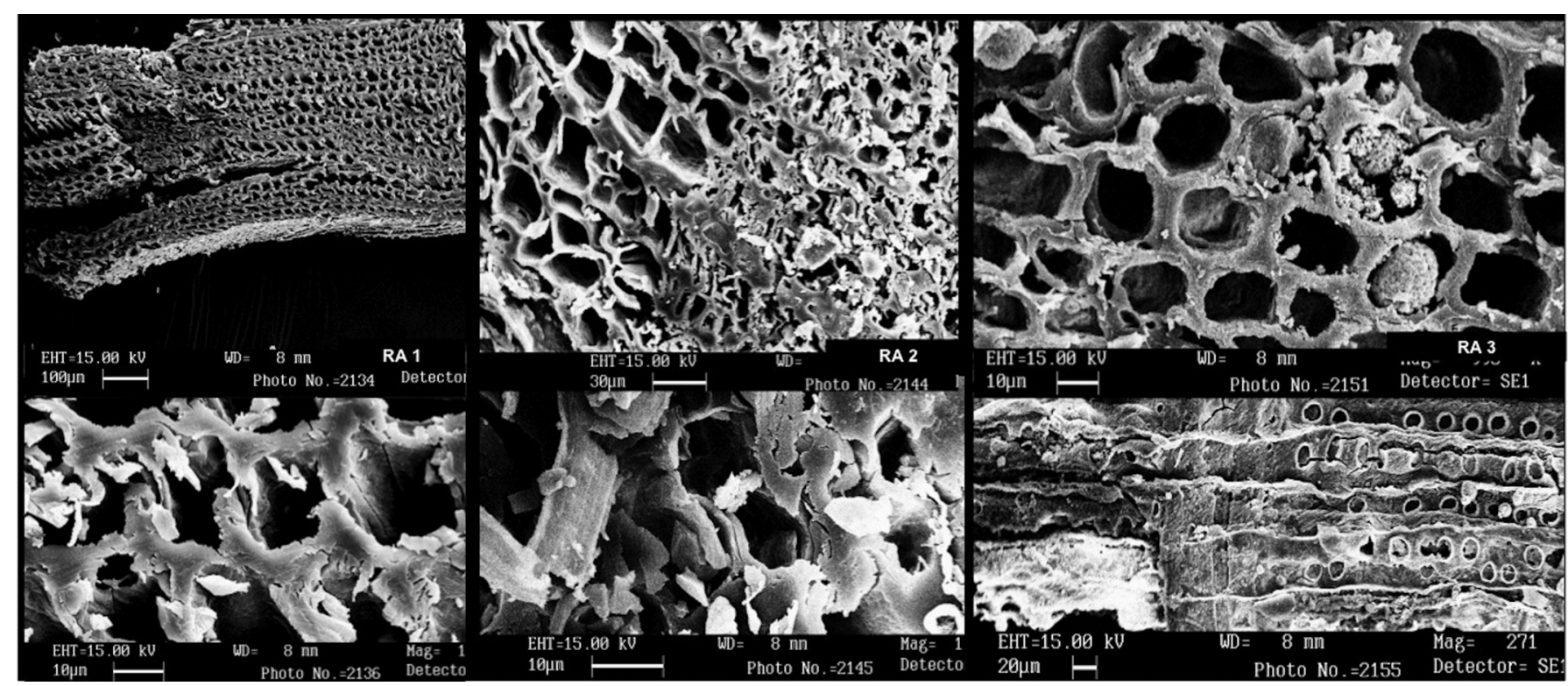

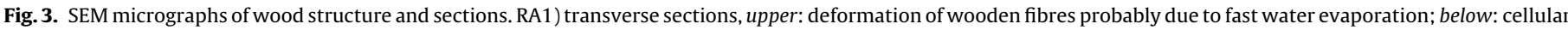

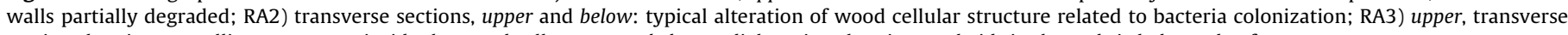
section showing crystalline aggregates inside the wood cell structure; below, radial section showing tracheids in the embrittled wooden fragments.

$72{ }^{\circ} \mathrm{C}$ for $2 \mathrm{~min}$. A final extension step $\left(72^{\circ} \mathrm{C}\right.$ for $\left.7 \mathrm{~min}\right)$ was added to ensure that all PCR products were full-length.

DNA fragments corresponding to 16 S locus or ITS region amplification were purified by Quick PCR purification kit (QIAGEN) and the sequences determined by Eurofin MWG operon service (http://www.eurofins.com).

The homology research was undertaken on 16S or ITS rDNA sequences, by BLAST analyser (http://blast.ncbi.nlm.gov) [15].

SEM analysis on wood fragments was performed by Leica microscope LEO-400, after have being coated with gold micro-particles (CAR AGAR sputter coater) [9].

\section{Results and discussion}

It is well known that in degradation of marine waterlogged wood different processes occur, such as accumulation of reduced sulphur compounds, biological deterioration due to bacteria, fungi, marine bacteria and borer $[2,5,16]$. The aim of this study is to set up a technical protocol for revealing and characterizing bacterial colonization of waterlogged wood, in order to perform a correct diagnosis, indispensable for an adequate conservation strategy.

Wooden structure (radial and cross sections) and relative alterations (RA1, RA2 and RA3 samples) were observed by Optical and Scanning Electron Microscopy. Results in Figs. 2 and 3 showed the altered structure of wood and revealed the presence on the surface of several chromatic spots, green and dark (thiols, iron sulphides), probably due to both bacterial consortia and environmental conditions.

Table 1

Bacterial species identified by molecular analysis.

\begin{tabular}{|c|c|c|c|}
\hline \multirow[t]{2}{*}{ Samples } & \multirow{2}{*}{$\begin{array}{l}\text { DNA from } \\
\text { isolated colonies } \\
\text { ITS - PCR }\end{array}$} & \multicolumn{2}{|c|}{ DNA from wood fragments } \\
\hline & & ITS - PCR & $16 S-P C R$ \\
\hline AR1 & $\begin{array}{l}\text { Pseudomonas sp. } \\
\text { Cellulomonas sp. }\end{array}$ & $\begin{array}{l}\text { Desulforudis } \\
\text { audaxviator }\end{array}$ & $\begin{array}{l}\text { Pseudomonas sp. } \\
\text { Cellulomonas sp. }\end{array}$ \\
\hline AR2 & $\begin{array}{l}\text { Pseudomonas sp. } \\
\text { Cellulomonas sp. }\end{array}$ & Sphingomonas sp. & $\begin{array}{l}\text { Pseudomonas sp. } \\
\text { Cellulomonas sp. }\end{array}$ \\
\hline AR3 & $\begin{array}{l}\text { Pseudomonas sp. } \\
\text { Xanthomonas sp. }\end{array}$ & Marinobacter sp. & Pseudomonas sp. \\
\hline
\end{tabular}

Molecular investigation results, showed in Table 1, confirm the presence of bacteria such as Cellulomonas sp., Sphingomonas sp., Xanthomonas sp, as well as Marinobacter sp. (iron-oxidant bacteria) and Desulforudis sp. (sulphate-reducing bacteria).

Moreover, cross and radial sections of each wood fragment have been observed by light microscopy, at a magnification range $\times 10$, 5-40 (reflected light) and $\times 40-200$ (transmitted light), identifying the samples as Pinus sp. (B. Megna personal communication).

Considering the complexity of degradation microbial of waterlogged wood, the current study contribute to enrich the knowledge on the bacterial consortia colonizing waterlogged wood recovered in Sicilian sea area.

\section{Acknowledgements}

We especially thank the Soprintendenza del Mare della Regione Siciliana, and particularly Sebastiano Tusa and Cecilia Buccellato. Authors would like to acknowledge Anna M. Mannino (DAB, University of Palermo) for SEM observation and Bartolomeo Megna (DICAA, University of Palermo) for wood identification.

This study was partially supported by research activity (F. Palla - ex 60\%) MIUR-University of Palermo.

\section{References}

[1] S. Tusa, Research - protection and evaluation of Sicilian and Mediterranean marine cultural heritage, Conservation Science in Cultural Heritage 9 (2009) 79-98.

[2] M. Jones, The seabed enviroment, in: M. Jones (Ed.), The Archaeology of the Mary Rose 5, The Mary Rose Trust, Portsmouth, UK, 2003.

[3] R.A. Blanchette, A review of microbial deterioration found in archaeological wood from different environments, International Biodeterioration \& Biodegradation 46 (2000) 189-204.

[4] T. Steffen, A. Salmi, J. Eskelinen, L. Montonen, A. Serima, E. Haeggstrom, Microbial degradation of the 18th century Dutch merchant vessel Vrouw Maria, in: C. Urzì (Ed.), Proceedings of 14th International Biodeterioration and Biodegradation Symposium, Messina 6-11 October, Italy, 2008, p. 53.

[5] G. Daniel, T. Nilsson, Development in the study of soft rot and bacterial decay, in: A. Bruce, J. Palfreyman (Eds.), Forest Products Biotechnology, 1998, pp. 37-62.

[6] C. Björdal, T. Nilsson, Waterlogged archaeological wood-substrate for white fungi during drainage of wetlands, International Biodeterioration \& Biodegradation 46 (2000) 189-204.

[7] T. Nilsson, C. Björdal, Culturing wood-degrading erosion bacteria, International Biodeterioration \& Biodegradation 61 (2008) 17-23. 
[8] T. Nilsson, C. Björdal, E. Fallman, Culturing erosion bacteria: procedures for obtaining purer cultures and pure strains, International Biodeterioration \& Biodegradation 61 (2008) 17-23.

[9] M. Manders, Underwater cultural heritage at risk - managing natural and human impact, heritage at risk, in: Special Edition ICOMOS, 2006, pp. 70-72.

[10] F. Palla, L. Anello, S. Marineo, G. Lombardo, Characterisation of bacterial communities in indoor environment, in: R. Fort, M. Alvarez de Buergo, M Gomez-Heras, C. Vazquez-Calvo (Eds.), Heritage, Watering and Conservation, Taylor \& Francis Group, London/Leiden/NewYork/Philadelphia/Singapore, 2006, pp. 361-365.

[11] F. Palla, C. Federico, R. Russo, L. Anello, Identification of Nocardia restricta in biodegraded sandstone monuments by PCR and nested-PCR amplification, FEMS Microbiology Ecology 39 (2002) 85-89.

[12] X. Chen, Y. Zeng, N. Jiao, Development and evaluation of specific 16S rDNA primers for marine Cytophaga-Flavobacteria cluster, Molecular Ecology Notes 6 (2006) 1278-1281;
T. Nilsson, C. Björdal, Culturing wood-degrading erosion bacteria, International Biodeterioration \& Biodegradation 61 (2008) 3-10.

[13] J. Mergaert, D. Lednická, J. Goris, M.C. Cnockaert, P. De Vos, J. Swings, Taxonomic study of Cellvibrio strains and description of Cellvibrio ostraviensis sp. nov., Cellvibrio fibrivorans sp. nov. and Cellvibrio gandavensis sp. nov., Journal of Systematic and Evolutionary Microbiology 53 (2003) 465-471.

[14] M. Cardinale, L. Brusetti, P. Quatrini, S. Borin, A.M. Puglia, A. Rizzi, E. Zanardini, C. Sorlini, C. Corselli, D. Daffonchio, Comparison of different primer sets for use in automated ribosomal intergenic spacer analysis of complex bacterial communities, Applied and Environmental Microbiology 70 (2004) 6147-6156.

[15] S.F. Altschul, T.L. Madden, A.A. Schäffer, J.Zhang, Z.Zhang, W. Miller, D.J. Lipman, Gapped BLAST and PSI-BLAST: a new generation of protein database search programs, Nucleic Acids Research 25 (1997) 3389-3402.

[16] C.G. Björdal, Understanding microbial degradation of waterlogged archaeological wood, in: L. Uzielli (Ed.), Wood Sciences for Conservation of Cultural Heritage, Firenze University Press, 2009, pp. 123-127. 